\title{
Soil organic carbon and dead biomass pools in woodlands from Monte region (Argentina)
}

\author{
Reservorios de carbono orgánico del suelo y biomasa muerta \\ en áreas forestales de la región Monte (Argentina)
}

\author{
Marcos S Karlin ${ }^{a *}$, Ricardo M Zapata ${ }^{\text {a }}$, Rubén O Coirini ${ }^{\text {a,b }}$ \\ *Corresponding author: ${ }^{a}$ Universidad Nacional de Córdoba, Facultad de Ciencias Agropecuarias, Departamento Recursos Naturales, \\ Félix Marrone 746, Ciudad Universitaria, CC 509, CP 5000, Córdoba, Argentina, mkarlin@agro.unc.edu.ar \\ ${ }^{\mathrm{b}}$ Red Agroforestal Chaco Argentina, San Lorenzo 1235 Reconquista, CP: 3560, Santa Fe, Argentina.
}

\begin{abstract}
SUMMARY
Soil and above-ground dead biomass are important carbon pools in drylands. They depend on local controls and patterns that should be studied. The objective of this work is to understand and quantify the influence of the vegetation canopy in the regulation of soil and dead biomass carbon stocks in woodlands of Monte region in Argentina. The hypothesis is that soil and dead biomass carbon stocks are lower in the intercanopy and higher under the canopy, independently of the type of canopy. Thirty sampling plots were selected, identifying three treatments: tree canopy, intercanopy and shrub canopy. In each sampling plot, soil and dead biomass were sampled. Four physiognomic-functional groups were identified. Prosopis woodlands accumulated about $38 \mathrm{Mg}^{-1}$ of dead organic carbon (from soil, litter, and dead wood), followed by Suaeda woodlands with almost $35 \mathrm{Mg} \mathrm{ha}^{-1}$. Mixed woodlands showed average values around $27 \mathrm{Mg} \mathrm{ha}^{-1}$, while Bulnesia woodlands around $25 \mathrm{Mg} \mathrm{ha}^{-1}$. The vegetation canopy, and consequently, litter and dead wood input affected soil organic carbon in topsoil. Shrubs such as Larrea spp. had a restricted ability to enrich soil compared to Prosopis spp. Soil, litter and dead wood are significant pools of carbon and should be included in programs on reducing emissions in arid regions. The hypothesis is accepted partially; there is a remarked contrast in carbon content between soils under the tree canopy and off the canopy. However, the effect of shrub canopy is intermediate between both treatments.
\end{abstract}

Key words: litter, shrub, tree canopy, dead wood.

\section{RESUMEN}

El suelo y la biomasa muerta son importantes reservorios de carbono en zonas áridas. Ellos dependen de patrones y factores locales que deben ser estudiados. El objetivo de este trabajo fue cuantificar la influencia del dosel de la vegetación en los contenidos de carbono del suelo y de la biomasa muerta en áreas forestales de la región Monte en Argentina. La hipótesis es que los contenidos de carbono en el suelo y en la biomasa muerta son menores fuera del dosel y mayores bajo dosel, independientemente del tipo de dosel. Treinta parcelas de muestreo fueron seleccionadas, identificando tres tratamientos: bajo dosel arbóreo, espacio sin dosel y bajo dosel arbustivo. Se muestrearon suelo y biomasa muerta. Se identificaron cuatro grupos fisonómico-funcionales. Los bosques de Prosopis spp. acumularon $\sim 38 \mathrm{Mg} \mathrm{ha}^{-1}$ de carbono orgánico muerto (suelo, mantillo y madera muerta), las áreas forestales de Suaeda spp. $\sim 35 \mathrm{Mg} \mathrm{ha}^{-1}$, los bosques mixtos $\sim 27 \mathrm{Mg} \mathrm{ha}^{-1} \mathrm{y}$ los bosques de Bulnesia spp. $\sim 25 \mathrm{Mg} \mathrm{ha}^{-1}$. El dosel de la vegetación y, consecuentemente, los aportes de mantillo y madera muerta influyeron en los contenidos de carbono del suelo superficial. Arbustos como Larrea spp. tienen menor capacidad para enriquecer el suelo que Prosopis spp. El suelo, mantillo y madera muerta son reservorios significativos de carbono y deberían ser considerados en programas de reducción de emisiones en zonas áridas. La hipótesis fue parcialmente aceptada; hay un marcado contraste en los contenidos de carbono entre suelos bajo y fuera del dosel. Sin embargo, el efecto del dosela arbustivo es intermedio entre ambos tratamientos.

Palabras clave: mantillo, arbusto, canopia arbórea, madera muerta.

\section{INTRODUCTION}

Soils are an important carbon sink in ecosystems worldwide. Trees, shrubs and herbs can assimilate $\mathrm{CO}_{2}$ from the atmosphere and transform it into biomass. Some of above-ground or subterranean tissues may be assimila- ted into the soil profile, enriching it with organic carbon. Carbon stocks in ecosystems are the result of the balance between the rates of accumulation and decomposition.

Accumulation rates depend on the net primary production of vegetation, which in turn depends on solar radiation, air temperature, nutrients and water, needed for 
plants to grow (Jobbágy and Jackson 2000). Plants physiology and architecture, e.g., deciduousness or canopy volume, also affect carbon accumulation. Decomposition rates depend on soil characteristics and the microclimate under the canopy.

Plants in arid lands have a restricted growth due to harsh environmental conditions such as scarcity of water and nutrients. Only adapted species can develop under arid and hyperarid conditions, and they usually grow in communities within fertile small-scaled patches. Woody plants in arid zones are the primary microclimate regulators, not only by attenuating drastic changes in air temperature and humidity, but also altering soil conditions under the canopy (Rossi and Villagra 2003).

Soil is the most abundant organic carbon pool in the terrestrial biosphere, compared to vegetation and animals. Although many authors studied soil organic matter and litter carbon contents in natural ecosystems (Yang et al. 2007), and specifically in arid zones (Charley and West 1975, Rossi and Villagra 2003), local controls should be studied more thoroughly (Yang et al. 2007). Such local controls are defined by local climate, soil type and dominant vegetation.

Covering about $47 \%$ of the total terrestrial surface, drylands hold $27 \%$ of the global soil organic carbon reserves (Trumper et al. 2008). Desertification may reduce such carbon reserves. With 50,678,905 ha (Karlin et al. 2017), Monte region represents $18 \%$ of the total continental area of Argentina, being an important carbon sink due to its extension. It also holds some biogeographic similarities with other regions of South America, North of Mexico and South of the USA (Roig et al. 2009). The study of soil carbon stocks in this region might produce relevant information for ecosystem management and conservation practices in arid zones, e.g., for plants arrangement within agroforestry experiences.

The objective of this work is to understand and quantify the influence of the vegetation canopy in the regulation of soil and dead biomass carbon contents in woodlands of Monte region in Argentina. Since the influence of shrubs on carbon inputs is poorly understood, they were compared with the tree canopy effect. The amounts of carbon accumulated in the soil, litter and dead wood in Monte woodlands have been quantified, considering three different treatments: under tree canopy, under shrub canopy and intercanopy.

The hypothesis is that independently of the type of canopy (trees or shrubs; deciduous or semideciduous), the soil, litter and dead biomass carbon stocks in woodlands of Monte region are lower in the intercanopy and higher under the canopy.

\section{METHODS}

Study area. Monte region is an extended area of about $50 \mathrm{mi}-$ llion ha, stretched along $21^{\circ}$ of latitude $\left(23^{\circ} 12^{\prime}\right.$ to $\left.44^{\circ} 20^{\prime} \mathrm{S}\right)$ at the east of the Andes, and it is the most arid rangeland in Argentina. The elevation ranges between 0 and 3,000 m above sea level (Karlin et al. 2017). Water table depth is variable, nonetheless it is usually shallow in forest areas within valleys. The primary soil use is for forestry of native species and extensive livestock of variable intensity. Monte region can be divided into two districts, according to its dominant topography: Southern Monte (of plains and plateaus) and Northern Monte (of mountains and valleys), limiting at $32^{\circ} 50^{\prime} \mathrm{S}$ latitude (Morello 2012). Despite its extension, the climate, physiognomy and floristic composition, it is relatively homogeneous. Nevertheless, soil features are highly diversified due not only to soil genesis but to anthropic effects such as logging and overgrazing, inducing erosion. Southern Monte is a sandy plain of quaternary fluvial, lacustrine and aeolian origin. Northern Monte is a mountainous area furrowed by intermittent rivers shaping the relief, in which margins the vegetation makes use of the resulting moisture, sometimes resulting in dense forests (Abraham et al. 2009).

The climate is arid, with high evapotranspiration rates. Mean annual rainfall varies between $<100$ and $450 \mathrm{~mm}$, concentrated in summer, and it is strongly conditioned by topography. Mean annual temperature varies between 10 and $18^{\circ} \mathrm{C}$; the lowest means occur in Northern Monte, with topography-dependent isotherms (Abraham et al. 2009). Monte region is a steppe dominated by shrublands of $L a-$ rrea spp. intertwined with open or closed patches of Prosopis spp., Geoffroea decorticans (Gillies ex Hook. et Arn.) Burkart, and Bulnesia retama (Gillies ex Hook. et Arn.) Griseb, (among other species) tree communities. The main species living in Monte region are condensed in table 1, based on Flores et al. (2015) and Oyarzábal et al. (2018).

The sampling plots were located according to the sampling grid design for the Second National Inventory of Native Forests (Strada et al. 2011), consisting of $10 \mathrm{~km}$ equidistant points. Sampling plots presenting more than $20 \%$ of tree cover and average height up to $3 \mathrm{~m}$ (Argentinian Federal Council for the Environment 2012) and ease of access using $4 \mathrm{x} 4$ vehicle and within $2 \mathrm{~km}$ by foot from the vehicle were also selected. According to these criteria, 30 sampling plots were selected within Monte region (figure 1), ten from Southern Monte and 20 from Northern Monte. Samplings were made between July and November of 2018, during the dry and windy season.

Physiognomic-functional traits classification. In each sampling plot, a plant characterization was made by the phytosociological method (Braun-Blanquet 1979). The sampled area was defined by a radius of $20 \mathrm{~m}$ from the central point of the sample plot. Values of cover-abundance of all present plant species were transformed into percent cover values based on the midpoint of each value on the scale (Braun-Blanquet 1979).

With this data, a physiognomic-functional classification of the surveyed woodlands was obtained through con- 
glomerate and discriminant analyses. This classification defined environments with different carbon dynamics.

Sampling design. In each sampling plot, $20 \mathrm{~m}$ long transects were located towards the four cardinal directions (north, south, east, west). Over each transect, two sites were selected as different treatments: under tree canopy (UT) and intercanopy (IC) (figure 2). When any of the described treatments were not present along a transect, samples were taken under shrub canopy (US). A tree is defined as a woody, perennial plant species when over 3 $\mathrm{m}$ tall, with one or multiple trunks differentiated from the

Table 1. List of the main species living in Monte region.

Lista de las principales especies que viven en la región del Monte.

\begin{tabular}{|c|c|c|}
\hline Family & Species & Habit \\
\hline Asteraceae & Baccharis salicifolia (Ruiz et Pav.) Pers. & Shrub \\
\hline Asteraceae & Chuquiraga erinacea D. Don & Shrub \\
\hline Capparaceae & Atamisquea emarginata Miers ex Hook. et Arn. & Shrub or tree \\
\hline Celastraceae & Maytenus viscifolia Griseb. & Tree \\
\hline Chenopodiaceae & Allenrolfea vaginata (Griseb.) Kuntze & Shrub \\
\hline Chenopodiaceae & Atriplex lampa (Moq.) D. Dietr. & Shrub \\
\hline Chenopodiaceae & Suaeda divaricata Moq. & Shrub \\
\hline Euphorbiaceae & Jatropha excisa Griseb. & Shrub \\
\hline Fabaceae & Vachellia aroma (Gillies ex Hook. et Arn.) Seigler et Ebinger & Shrub or tree \\
\hline Fabaceae & Senegalia gilliesii (Steud.) Seigler et Ebinger & Tree \\
\hline Fabaceae & Parkinsonia praecox (Ruiz et Pav. ex Hook.) Hawkins & Shrub \\
\hline Fabaceae & Geoffroea decorticans (Gillies ex Hook. y Arn.) Burkart & Tree \\
\hline Fabaceae & Prosopis alpataco Phil. & Shrub \\
\hline Fabaceae & Prosopis chilensis (Molina) Stuntz emend. Burkart & Tree \\
\hline Fabaceae & Prosopis flexuosa DC. & Tree \\
\hline Fabaceae & Prosopis strombulifera (Lam.) Benth. var. strombulifera & Shrub \\
\hline Fabaceae & Zuccagnia punctata Cav. & Shrub \\
\hline Fabaceae & Parasenegalia visco (Lorentz ex Griseb.) Seigler et Ebinger & Tree \\
\hline Nyctaginaceae & Bougainvillea spinosa (Cav.) Heimerl & Shrub \\
\hline Plantaginaceae & Monttea aphylla (Miers) Benth. y Hook. & Shrub \\
\hline Poaceae & Aristida mendocina Phil. & Grass \\
\hline Poaceae & Jarava ichu Ruiz et Pav. & Grass \\
\hline Poaceae & Leptochloa crinita (Lag.) P.M. Peterson et N.W. Snow & Grass \\
\hline Salicaceae & Salix humboldtiana Willd. & Tree \\
\hline Solanaceae & Lycium boerhaviaefolium L. f. & Shrub \\
\hline Solanaceae & Lycium chilense Miers ex Bertero & Shrub \\
\hline Ximeniaceae & Ximenia americana $\mathrm{L}$. & Shrub or tree \\
\hline Zygophyllaceae & Bulnesia retama (Gillies ex Hook. et Arn.) Griseb. & Shrub or tree \\
\hline Zygophyllaceae & Larrea cuneifolia Cav. & Shrub \\
\hline Zygophyllaceae & Larrea divaricata Cav. & Shrub \\
\hline Zygophyllaceae & Larrea nitida Cav. & Shrub \\
\hline Zygophyllaceae & Plectrocarpa tetracantha Gillies ex Hook. et Arn. & Shrub \\
\hline
\end{tabular}


crown. A shrub is defined as a woody, perennial plant species when under $3 \mathrm{~m}$ tall, according to Guideline \#1.2 Res. 230/12 of the Argentinian Federal Council for the Environment (COFEMA 2012), with the crown undifferentiated from the trunk. In each treatment, the tree and shrub species were identified.

The woody species were classified into two groups, according to deciduousness. Deciduous species are those losing their vegetative or reproductive tissues along a pe- riod larger than six months without significant seasonality effects. Semideciduous species are those losing their vegetative or reproductive tissues sporadically or concentrated in only one season. The last group includes those species considered as aphyllous. The deciduous species are represented by Prosopis spp., Geoffroea decorticans, Mimozyganthus carinatus, Atamisquea emarginata, Plectrocarpa tetracantha, Vachellia aroma, and Allenrolfea spp. (the last by the release of their strobiles). The semideciduous

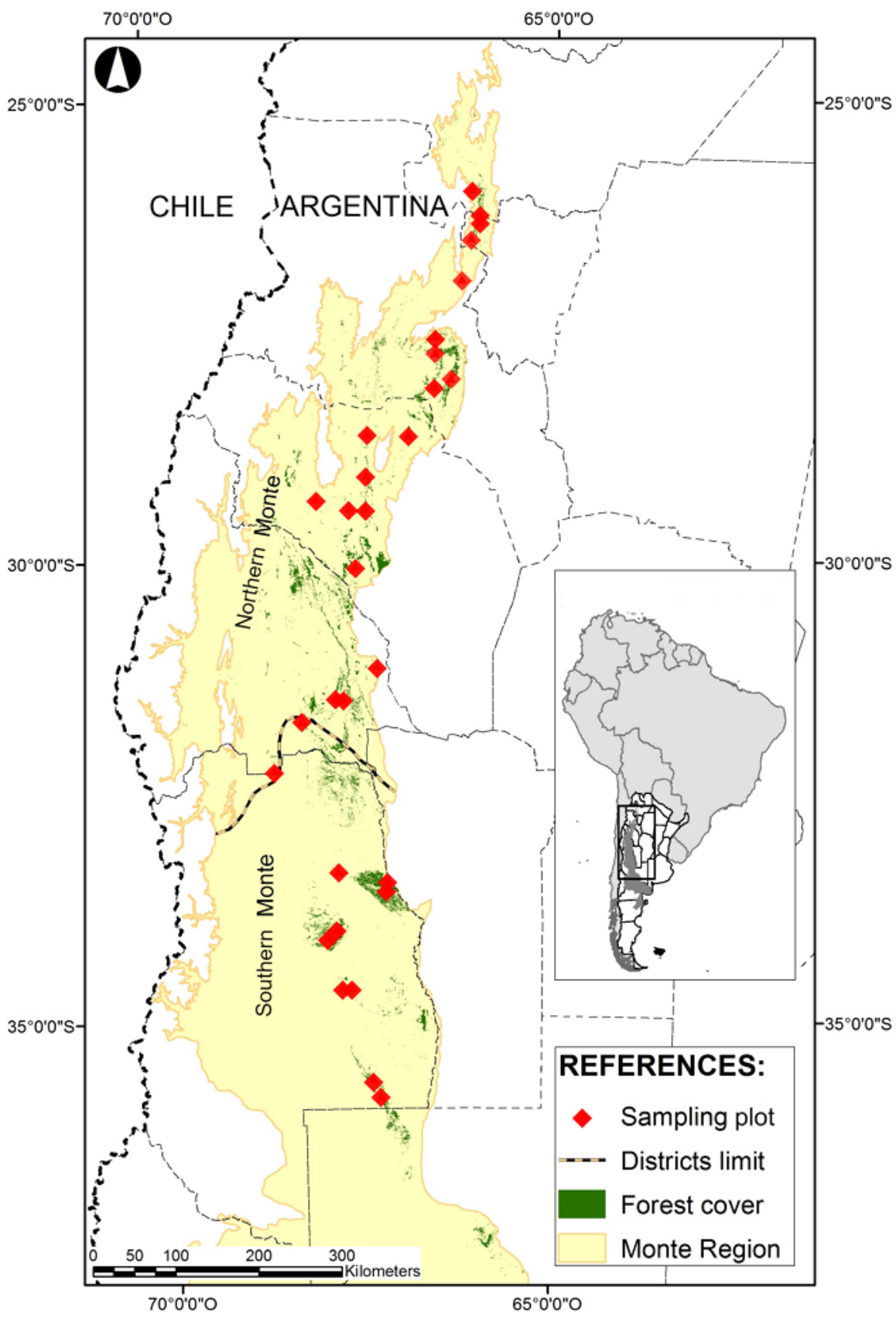

Figure 1. Sampling area in Monte region. $\$$ : Sampling plots. Dark (green) areas: Forest cover. 
species are represented by Bulnesia retama, Larrea spp., Condalia microphylla, and Suaeda divaricata.

Along each transect, plant cover was measured as the projection of the crown, defining tree and shrub cover in percent. The sectors without crown projection along the transects were identified as intercanopy. In each site, a quadrat of $0.25 \mathrm{~m}^{2}$ was placed to delimit the area for soil and litter sampling. Over each transect, a strip of $10 \times 2$ $\mathrm{m}$ was defined to measure the dead wood presenting more than $5 \mathrm{~cm}$ diameter (figure 2).

Soil bulk density. A $7 \mathrm{~cm}$ diameter and $7 \mathrm{~cm}$ height Kopecky cylinder was used to extract undisturbed soil samples for bulk density measurement. The most representative transect in each sample plot was selected, resulting in four soil samples per sample plot: under tree canopy and intercanopy (or under shrub canopy) at 0-7 cm depth and 10-17 cm depth.

Soil samples were carefully pulverized without losing any material and air-dried at $60{ }^{\circ} \mathrm{C}$ in a forced-air chamber for three days and weighed. The soil bulk density was the result of the ratio between the dry weight of the sample and the cylinder volume. When soil samples could not be extracted due to the presence of rocks and gravel, soil bulk density was estimated according to its texture, determined by feel analysis (Thien 1979).
With the soil bulk density, soil mass $(S M)$ in $\mathrm{Mg} \mathrm{ha}^{-1}$ was determined for each sample plot, depth and treatment.

Soil organic carbon stocks. In each site (under tree canopy and intercanopy -or under shrub canopy-) of each transect, soil samples were taken at $0-5 \mathrm{~cm}$ and $5-20 \mathrm{~cm}$ depth, following the results of Charley and West (1975). Significant differences in arid soil organic carbon content between these layers were noted. In 20 sites, topsoil samples could not be taken due to the presence of rocks and gravel. In three sample plots from Northern Monte, no $5-20 \mathrm{~cm}$ depth samples were taken in any transect for the same reason.

Soil samples were pulverized, sieved and air-dried at $60{ }^{\circ} \mathrm{C}$ in a forced-air chamber for three days. Soil organic carbon content $(\% \mathrm{C})$ was determined by the method of Walkley and Black (Nelson and Sommers 1974).

Once $\% C_{s}$ was determined, soil organic carbon stock $\left(C_{s}\right)$ was calculated in $\mathrm{Mg} \mathrm{ha}^{-1}$ at the $i^{\text {th }}$ depth, for the $j^{\text {th }}$ treatment:

$$
C_{s(i, j)}=S M_{(i, j)} * \% C s_{(I, j)} / 100
$$

For the determination of soil organic carbon stock per hectare, weighted by the cover $\left(C_{s W}\right)$, for each sample plot

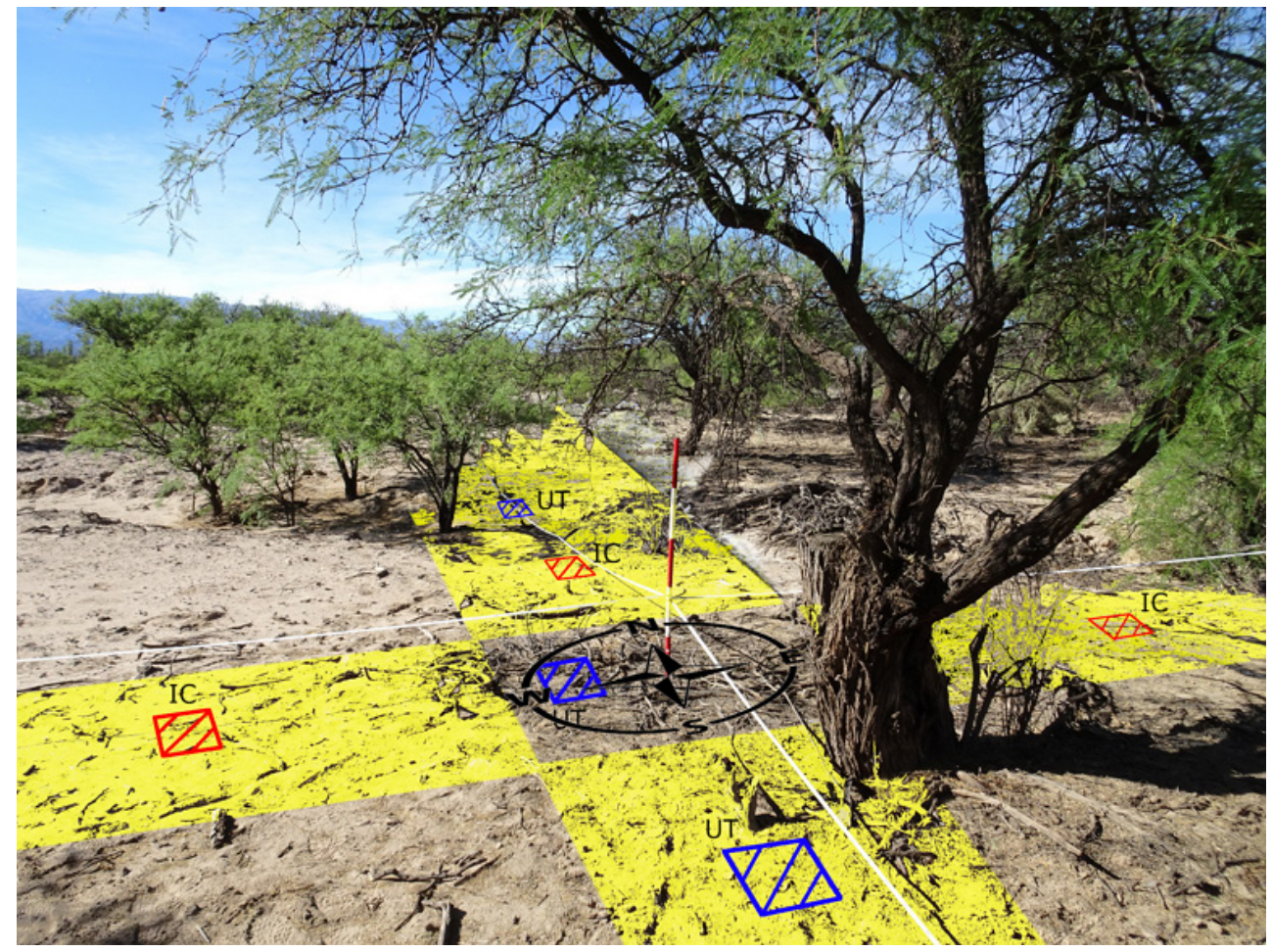

Figure 2. Sampling design for each sampling plot. Lighted strips: 10 × $2 \mathrm{~m}$ strips for measuring the volume of dead wood with diameter $>5 \mathrm{~cm}$; UT quadrats: under tree canopy treatment; IC quadrats: intercanopy treatment. Photo: R. Zapata.

Diseño del muestreo en cada parcela. Fajas claras: bandas de $10 \times 2 \mathrm{~m}$ para la medición de volúmenes de madera muerta de diámetro $>5$ cm; cuadrantes UT: tratamiento bajo canopia arbórea; cuadrantes IC: tratamiento de intercanopia. Foto: R. Zapata. 
at the $i^{\text {th }}$ depth and the $j^{\text {th }}$ treatment, the following calculation was made:

$$
C_{s W(i, j)}=\sum_{j}\left(\frac{\sum_{n}\left(C_{s n} * C o b\right)}{n}\right)_{i}
$$

where $\frac{\sum_{n}\left(C_{\left.s n^{* C o b}\right)}\right.}{n}$ is the average value $\left(\mathrm{Mg} \mathrm{ha}^{-1}\right)$ of the $n$ repetitions for the $C_{s}$ values, weighted by the canopy percentage.

Litter carbon stocks. In each quadrat, litter and dead wood between 1 and $5 \mathrm{~cm}$ of diameter were collected separately. No alive grass or herbs were collected, only dead biomass. Samples were air-dried at $60{ }^{\circ} \mathrm{C}$ in a forced-air chamber for three days and weighed. From each litter sample, a subsample was extracted, weighed, minced and burned in a muffle furnace (Navarro et al. 1993). The muffle was preheated at $100{ }^{\circ} \mathrm{C}$ for $4 \mathrm{~h}$, and afterwards the temperature was increased to $550^{\circ} \mathrm{C}$ for $5 \mathrm{~h}$ more. The burned subsample was extracted and weighed, calculating the percentage of organic matter of the sample $\left(\% O M_{L}\right)$ from the difference. These values were converted into carbon percentages $\left(\% C_{L}\right)$ by using the conversion formula of Navarro et al. (1993):

$$
\% C_{L}=\% O M_{L} * 0.51+0.48
$$

Litter carbon stock $\left(C_{L}\right)$ was obtained and extrapolated to an area of 1 ha by multiplying the product of litter mass $(L M)$ and $\% C_{L}$ by $40,000\left(0.25 \mathrm{~m}^{2}\right.$ quadrats in $\left.10,000 \mathrm{~m}^{2}\right)$.

For the determination of the litter carbon stock in $\mathrm{Mg}$ $\mathrm{ha}^{-1}$, weighted by the cover $\left(C_{L W}\right)$ in each sample plot, the following calculation was made:

$$
C_{L W(j)}=\sum_{j}\left(\frac{\sum_{n}\left(C_{L n} * C o b\right)}{n}\right)_{j}
$$

Where, $\frac{\sum_{n}\left(C_{L n} * C o b\right)}{n}$ is the average value $\left(\mathrm{Mg} \mathrm{ha}^{-1}\right)$ of the $n$ repetitions of the $C_{L}$ values, weighted by the canopy cover percentage, and $j$ represents each treatment.

The ratio between the weighted litter carbon stocks under tree and shrub canopy was calculated for each site. This ratio was obtained as an index to quantify the influence of each cover category regarding litterfall.

Dead wood (1 to $5 \mathrm{~cm}$ in diameter) carbon stocks. The dead wood between 1 and $5 \mathrm{~cm}$ in diameter was collected from the quadrats and weighed. Dead wood samples originated predominantly from the species Prosopis flexuosa and Bulnesia retama. The carbon percentage $\left(\% C_{D W}\right)$ of one sample of $P$. flexuosa and two samples of $B$. retama were analyzed by the same method and conversion formula as that of litter [3]. Navarro et al. (1993) demonstrated that the percentage of carbon in wood is homogeneous.

The carbon stock of the dead wood samples was obtained by multiplying the dead wood mass and $\% C_{D W}$.
The weighted stock $\left(C_{D W<5 W}\right)$ in $\mathrm{Mg} \mathrm{ha}^{-1}$ of the dead wood $(1-5 \mathrm{~cm}$ in diameter) was calculated with the same formula as that of litter [4].

Dead wood (diameter $>5 \mathrm{~cm}$ ) carbon stocks. Diameter and height of the portions of dead wood branches found inside the $10 \times 2 \mathrm{~m}$ strips were measured for volume in each quadrant. Seven to nine wood samples per species were immersed in a beaker of water that was placed on a highprecision balance, and the weight of water displacement was converted into volume (Martínez-Cabrera et al. 2009). Afterwards, samples were dried in a chamber of forced air at $40{ }^{\circ} \mathrm{C}$ for $48 \mathrm{~h}$ and weighed. The average value of wood density per species was obtained. Carbon stock $\left(C_{D W>5}\right)$ was obtained by multiplying dead wood mass to $\% C_{D W}$.

The dead wood larger than $5 \mathrm{~cm}$ diameter was extrapolated to one hectare. The total dead wood stock larger than $5 \mathrm{~cm}$ diameter $\left(C_{D W>5}\right)$ per each sample plot was obtained by averaging the values in $\mathrm{Mg} \mathrm{ha}^{-1}$.

Statistical analyses. With the cover-abundance values, characteristic species were selected by discriminating those who had more than $3 \%$ of the cover, on average. With these species, a conglomerate analysis (average linkage; Phi coefficient) was performed for a first tentative classification. Subsequently, with the tentative classification, a discriminant analysis was performed. A physiognomicfunctional classification was finally obtained, identifying four plant clusters with different floristic characteristics.

The carbon stocks in each pool were compared between physiognomic-functional traits, treatments and plant deciduousness through ANOVA (LSD Fisher test). Simple regression analyses were made between different carbon pools. All the statistical analyses were performed with InfoStat statistical software (Di Rienzo et al. 2018).

\section{RESULTS}

Physiognomic-functional classification. From the phytosociological analysis, 12 species were selected as characteristic species: Prosopis flexuosa, Bulnesia retama, Lycium tenuispinosum, Geoffroea decorticans, Atamisquea emarginata, Larrea cuneifolia, Aristida adscensionis, Suaeda divaricata, Larrea divaricata, Jarava ichu, Condalia microphylla, and Prosopis alpataco.

The conglomerate and the discriminant analyses defined four physiognomic-functional groups (figure 3):

1) Communities of Suaeda divaricata, co-dominated by Prosopis flexuosa $(\mathrm{n}=2)$. They were present in mudlands, with silt loam Entisols and shallow water tables.

2) Mixed woodlands $(\mathrm{n}=8)$. Populations of P. flexuosa, $G$. decorticans, $L$. divaricata, and P. alpataco co-dominated in these woodlands. They were the dominant woody formations in the Southern Monte 
district, over Entisols with loamy sand (one plot), sandy loam (five plots), loam (one plot) or silt loam (one plot) textures.

3) Communities of P. flexuosa $(\mathrm{n}=8)$. P. flexuosa dominated, although some species such as $A$. emarginata or G. decorticans stood out. They were associated with Salids with loamy sand (two plots), sandy loam (three plots) or silt loam (one plot) topsoil textures, or Cambids with abundant gravel (2 plots).

4) Communities of $B$. retama $(n=12)$. Populations of $B$. retama were dominant, but $P$. flexuosa codominated sometimes. Their soils were diverse, from Argids or Cambids with abundant gravel and clay (two plots) to Salids (mudflats) with sandy loam (four plots) or silt loam (six plots) topsoil textures.

Soil organic carbon stocks. The soil organic carbon stock at 0-5 cm depth $\left(\mathrm{C}_{\mathrm{s} 0-5}\right)$ showed significant differences (table 2) between the intercanopy and tree canopy. The shrub canopy treatment showed no differences with the intercanopy or the tree canopy $(\mathrm{F}=14.01 ; P<0.0001 ; \mathrm{DF}=2)$. The intercanopy had approximately half the amount of soil organic carbon than that found under tree canopy treatment. The values shown in table 2 were derived from the following soil organic carbon percentages: $\mathrm{IC}=0.75 \pm$ $0.11 \%$; UT $=1.68 \pm 0.11 \%$; US $=1.16 \pm 0.21 \%$.

The soil organic carbon stock at $5-20 \mathrm{~cm}$ depth $\left(C_{s 5-20}\right)$ was significantly lower in the intercanopy than under the tree canopy $(\mathrm{F}=6.05 ; P=0.0030 ; \mathrm{DF}=2)$. Under shrub canopy showed no difference with either the intercanopy or the under-tree canopy treatment (table 2). The values shown in table 2 were derived from the following soil organic carbon percentages $\left(\% C_{s}\right)$ : IC $=0.61 \pm 0.07 \%$; $\mathrm{UT}=0.99 \pm 0.07 \%$; US $=0.78 \pm 0.12 \%$. Differences among treatments at $5-20 \mathrm{~cm}$ depth were less contrasting than those in the surface.

Soil organic carbon percentage $\left(\% C_{s}\right)$ showed significant differences between $0-5$ and $5-20 \mathrm{~cm}$ depth under tree canopy $(\mathrm{n}=139 ; \mathrm{F}=15.83 ; P<0.0001)$, and a marginal difference $(0.1>P>0.05)$ under shrub canopy $(\mathrm{n}=42$; $\mathrm{F}=3.60 ; P=0.0652)$ and in the intercanopy $(\mathrm{n}=143$; $\mathrm{F}=2.90 ; P=0.0908$ ).

When weighted by the cover percentages (table 2), soil organic carbon showed similar differences between treatments at the surface $(\mathrm{F}=3.93 ; P=0.0019 ; \mathrm{DF}=2)$, nevertheless did not differ statistically among treatments in the deeper layer $(\mathrm{F}=0.61 ; P=0.5466 ; \mathrm{DF}=2)$. The surveyed covered area (under tree canopy plus shrub canopy) was on average $40 \%$ of the total surface.

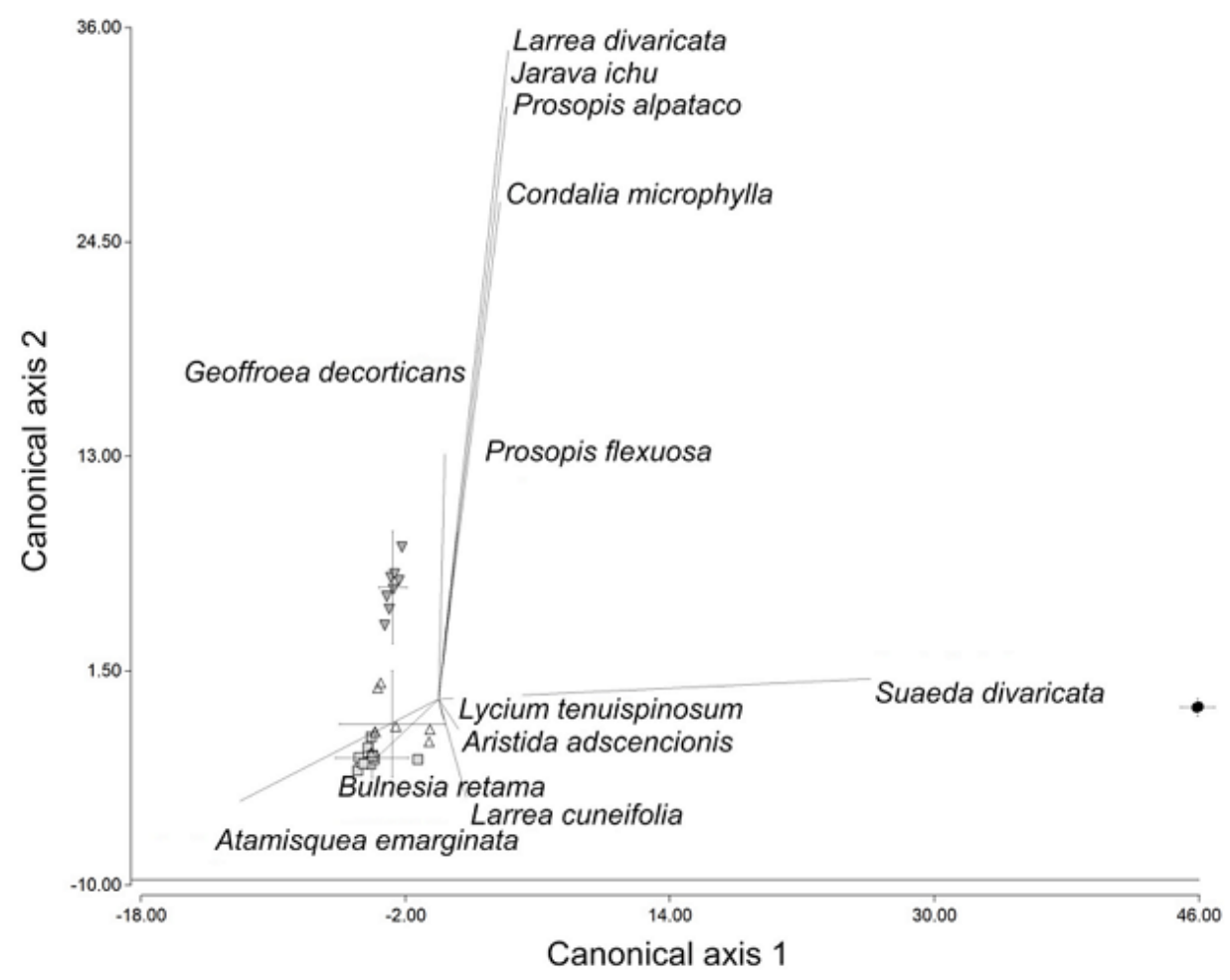

Figure 3. Discriminant analysis, with prediction intervals associated with the four groups: • communities of $S$. divaricata, codominated by P. flexuosa; $\nabla$, mixed woodlands; $\Delta$, communities of $P$. flexuosa; $\square$, communities of B. retama.

Análisis discriminante, con intervalos de predicción asociados a los cuatro grupos: $\bullet$, comunidades de $S$. divaricata, co-dominados por $P$. flexuosa; $\nabla$, bosques mixtos; $\Delta$, comunidades de P. flexuosa; $\square$, comunidades de B. retama. 
Table 2. Stocks $\left(\mathrm{Mg} \mathrm{ha}^{-1}\right)$ of soil organic carbon, litter carbon, and dead wood carbon, by treatment. IC: Intercanopy, UT: under tree canopy, US: under shrub canopy. Different letters show statistically significant differences among treatments at $P=0.05$.

Contenidos $\left(\mathrm{Mg} \mathrm{ha}^{-1}\right)$ de carbono orgánico del suelo, carbono de mantillo y carbono de madera muerta, por tratamiento. IC: espacio fuera del dosel, UT: bajo dosel arbóreo, US: bajo dosel arbustivo. Letras diferentes indican diferencias estadísticamente significativas entre tratamientos al $P=0,05$.

\begin{tabular}{|c|c|c|c|c|c|c|}
\hline \multirow{2}{*}{ Treatment } & & \multirow{2}{*}{ IC } & \multicolumn{2}{|c|}{ By soil cover } & \multicolumn{2}{|c|}{ By deciduousness } \\
\hline & & & UT & US & Semideciduous & Deciduous \\
\hline \multirow[b]{2}{*}{$\begin{array}{l}\text { Soil organic carbon stock } \\
\qquad(0-5 \mathrm{~cm} \text { depth })\end{array}$} & $\mathrm{n}$ & 74 & 72 & 21 & 27 & 66 \\
\hline & Mean & $\begin{array}{c}5.74 \pm 0.77 \\
(\mathrm{aA})\end{array}$ & $\begin{array}{l}11.52 \pm 0.78 \\
\text { (b) }\end{array}$ & $\begin{array}{c}8.33 \pm 1.44 \\
(\mathrm{ab})\end{array}$ & $\begin{array}{l}8.26 \pm 1.26 \\
\text { (A) }\end{array}$ & $\begin{array}{l}11.84 \pm 0.81 \\
\text { (B) }\end{array}$ \\
\hline \multirow{2}{*}{$\begin{array}{l}\text { Soil organic carbon stock } \\
\qquad(5-20 \mathrm{~cm} \mathrm{depth)}\end{array}$} & $\mathrm{n}$ & 69 & 67 & 21 & 25 & 63 \\
\hline & Mean & $\begin{array}{c}14.60 \pm 1.43 \\
(\mathrm{aA})\end{array}$ & $\begin{array}{c}21.76 \pm 1.47 \\
\text { (b) }\end{array}$ & $\begin{array}{c}18.26 \pm 2.62 \\
(\mathrm{ab})\end{array}$ & $\begin{array}{c}16.19 \pm 2.37 \\
\text { (A) }\end{array}$ & $\begin{array}{c}22.80 \pm 1.49 \\
\text { (B) }\end{array}$ \\
\hline \multirow{2}{*}{$\begin{array}{l}\text { Weighted soil organic carbon } \\
\text { stock } \\
(0-5 \mathrm{~cm} \text { depth })\end{array}$} & $\mathrm{n}$ & 74 & 72 & 21 & 27 & 66 \\
\hline & Mean & $\begin{array}{c}3.44 \pm 0.53 \\
(\mathrm{aA})\end{array}$ & $\begin{array}{l}5.53 \pm 0.54 \\
\text { (b) }\end{array}$ & $\begin{array}{c}3.93 \pm 1.00 \\
(\mathrm{ab})\end{array}$ & $\begin{array}{l}4.05 \pm 0.88 \\
\quad(\mathrm{AB})\end{array}$ & $\begin{array}{c}5.62 \pm 0.56 \\
\text { (B) }\end{array}$ \\
\hline \multirow{3}{*}{$\begin{array}{c}\text { Weighted soil organic carbon } \\
\text { stock } \\
(5-20 \mathrm{~cm} \text { depth })\end{array}$} & $\mathrm{n}$ & 69 & 67 & 21 & 25 & 63 \\
\hline & Mean & $8.79 \pm 1.70$ & $10.03 \pm 0.95$ & $8.33 \pm 1.70$ & $7.66 \pm 1.55$ & $10.40 \pm 0.98$ \\
\hline & $\mathrm{n}$ & 98 & 94 & 26 & 29 & 91 \\
\hline Litter carbon stock & Mean & $\begin{array}{c}0.38 \pm 0.39 \\
(\mathrm{aA})\end{array}$ & $\begin{array}{l}5.64 \pm 0.40 \\
\text { (b) }\end{array}$ & $\begin{array}{l}3.02 \pm 0.75 \\
\quad(\mathrm{c})\end{array}$ & $\begin{array}{l}2.68 \pm 0.70 \\
\quad(\mathrm{~B}) \\
\end{array}$ & $\begin{array}{c}5.83 \pm 0.39 \\
(\mathrm{C})\end{array}$ \\
\hline \multirow[b]{2}{*}{ Weighted litter carbon stock } & $\mathrm{n}$ & 98 & 94 & 26 & 29 & 91 \\
\hline & Mean & $\begin{array}{c}0.20 \pm 0.22 \\
(\mathrm{aA})\end{array}$ & $\begin{array}{l}2.67 \pm 0.22 \\
\text { (b) }\end{array}$ & $\begin{array}{l}1.76 \pm 0.42 \\
\quad(b)\end{array}$ & $\begin{array}{c}1.44 \pm 0.39 \\
(\mathrm{~B})\end{array}$ & $\begin{array}{c}2.81 \pm 0.22 \\
(\mathrm{C})\end{array}$ \\
\hline \multirow{2}{*}{$\begin{array}{l}\text { Dead wood carbon stock } \\
\quad(\text { diameter }<5 \mathrm{~cm})\end{array}$} & $\mathrm{n}$ & 98 & 94 & 26 & 29 & 91 \\
\hline & Mean & $\begin{array}{c}0.15 \pm 0.13 \\
(\mathrm{aA})\end{array}$ & $\begin{array}{l}1.05 \pm 0.13 \\
\text { (b) }\end{array}$ & $\begin{array}{c}0.67 \pm 0.24 \\
(\mathrm{ab})\end{array}$ & $\begin{array}{l}0.46 \pm 0.23 \\
(\mathrm{~A})\end{array}$ & $\begin{array}{c}1.14 \pm 0.13 \\
\text { (B) }\end{array}$ \\
\hline \multirow{2}{*}{$\begin{array}{l}\text { Weighted dead wood carbon } \\
\text { stock } \\
\text { (diameter }<5 \mathrm{~cm})\end{array}$} & $\mathrm{n}$ & 98 & 94 & 26 & 29 & 91 \\
\hline & Mean & $\begin{array}{c}0.09 \pm 0.08 \\
(\mathrm{aA})\end{array}$ & $\begin{array}{c}0.52 \pm 0.08 \\
\text { (b) }\end{array}$ & $\begin{array}{c}0.35 \pm(0.15) \\
(\mathrm{ab})\end{array}$ & $\begin{array}{c}0.24 \pm 0.14 \\
\text { (A) }\end{array}$ & $\begin{array}{c}0.56 \pm 0.08 \\
\text { (B) }\end{array}$ \\
\hline
\end{tabular}

Table 3. Stocks $\left(\mathrm{Mg} \mathrm{ha}^{-1}\right)$ of the weighted soil organic carbon, litter carbon and dead wood carbon, by physiognomic-functional group. Contenidos $\left(\mathrm{Mg} \mathrm{ha}^{-1}\right)$ del carbono orgánico del suelo ponderado, del carbono de la hojarasca y del carbono de la madera muerta, por grupo fisonómico-funcional.

\begin{tabular}{|c|c|c|c|c|c|}
\hline Group & & Comm. S. divaricata & Mixed woodland & Comm. P. flexuosa & Comm. B. retama \\
\hline \multirow{2}{*}{$\begin{array}{l}\text { Weighted soil organic carbon } \\
\text { stock }(0-5 \mathrm{~cm} \text { depth })\end{array}$} & $\mathrm{n}$ & 2 & 8 & 8 & 12 \\
\hline & Mean & $7.98 \pm 4.59$ & $7.56 \pm 2.30$ & $13.83 \pm 2.30$ & $7.09 \pm 1.88$ \\
\hline \multirow{2}{*}{$\begin{array}{l}\text { Weighted soil organic carbon } \\
\text { stock }(5-20 \mathrm{~cm} \text { depth })\end{array}$} & $\mathrm{n}$ & 2 & 8 & 7 & 10 \\
\hline & Mean & $20.04 \pm 5.60$ & $15.95 \pm 2.80$ & $21.28 \pm 2.99$ & $15.72 \pm 2.51$ \\
\hline \multirow{2}{*}{ Weighted litter carbon stock } & $\mathrm{n}$ & 2 & 8 & 8 & 12 \\
\hline & Mean & $2.60 \pm 1.57$ & $2.99 \pm 0.79$ & $3.85 \pm 0.79$ & $2.16 \pm 0.64$ \\
\hline \multirow{2}{*}{$\begin{array}{l}\text { Weighted dead wood carbon } \\
\text { stock (diameter }<5 \mathrm{~cm} \text { ) }\end{array}$} & $\mathrm{n}$ & 2 & 8 & 8 & 12 \\
\hline & Mean & $1.15 \pm 0.45$ & $0.38 \pm 0.23$ & $0.98 \pm 0.23$ & $0.34 \pm 0.18$ \\
\hline \multirow{2}{*}{$\begin{array}{l}\text { Dead wood carbon stock } \\
\quad(\text { diameter }>5 \mathrm{~cm})\end{array}$} & $\mathrm{n}$ & 2 & 8 & 8 & 12 \\
\hline & Mean & $2.41 \pm 1.25$ & $0.59 \pm 0.62$ & $2.20 \pm 0.62$ & $1.07 \pm 0.51$ \\
\hline \multirow{2}{*}{ Total carbon stock } & $\mathrm{n}$ & 2 & 8 & 7 & 10 \\
\hline & Mean & $34.18 \pm 8.53$ & $27.48 \pm 4.27$ & $38.62 \pm 4.56$ & $25.55 \pm 3.82$ \\
\hline
\end{tabular}


Deciduous plant cover showed significantly larger amounts of soil organic carbon mass (table 2 ) than those shown by semideciduous plant cover and the intercanopy $(0-5 \mathrm{~cm}: \mathrm{F}=$ $15.10, P<0.0001, \mathrm{DF}=2 ; 5-20 \mathrm{~cm} \mathrm{~F}=8.30, P=0.0004$, $\mathrm{DF}=2$ ). Deciduous plant cover differed at the surface from the intercanopy though not from the semideciduous cover $(\mathrm{F}=4.08, P=0.0186 ; \mathrm{DF}=2)$ in the weighted soil organic carbon stock (table 2). In the deeper layer, no significant differences were found ( $\mathrm{F}=1.34 ; P=0.2637 ; \mathrm{DF}=2)$.

When soil organic carbon stock was compared among physiognomic-functional groups at both depths (table 2), no significant differences were found in the average values per sample plot $(0-5 \mathrm{~cm}: \mathrm{F}=1.96, P=0.1446, \mathrm{DF}=3$; $5-20 \mathrm{~cm}: \mathrm{F}=0.87 ; P=0.4714, \mathrm{DF}=3)$. The sample plot with the largest contents of soil organic carbon stock for the $0-20 \mathrm{~cm}$ layer represented $47.44 \mathrm{Mg} \mathrm{ha}^{-1}$ in carbon. This plot was from a closed P. flexuosa woodland located in the Pipanaco saline basin (Catamarca).

The total soil organic carbon stock $(0-20 \mathrm{~cm})$ did not differ significantly between districts. Northern Monte District showed average values of $25.00 \pm 2.69 \mathrm{Mg} \mathrm{ha}^{-1}$ $(\mathrm{n}=17)$, while Southern Monte District had $26.44 \pm 3.50$ $\mathrm{Mg} \mathrm{ha}^{-1}(\mathrm{n}=10)(\mathrm{F}=0.11, P=0.7464)$. The former derived from the weighted average $(0-20 \mathrm{~cm}$ depth) in soil organic percentages of $1.32 \%$ under canopy and $0.66 \%$ in the intercanopy.

The soil organic carbon stock at both depths were significantly correlated $\left(C_{s 5-20}=5.98+1.47 * C_{s 0-5} ; \mathrm{R}^{2}=0.52\right.$; $P<0.0001 ; \mathrm{n}=157)$, indicating that subsoil carbon stock can be estimated by topsoil carbon stock with regression equation.

Litter carbon stocks. Despite the variety of materials accumulated as litter in the topsoil, litter carbon contents $\left(\% C_{L}\right)$ were relatively constant with $40.76 \%$ average, $41.89 \%$ median and $13.77 \%$ coefficient of variation $(n=212)$. No statistically significant differences were obtained between the litter carbon contents related to the covering species ( $\mathrm{n}=126 ; \mathrm{F}=0.94 ; P=0.5078)$. No difference was found comparing plant cover $(\mathrm{n}=212 ; \mathrm{F}=0.68 ; P=0.5073)$ or deciduousness $(\mathrm{n}=212 ; \mathrm{F}=0.94 ; P=0.3928)$.

Litter carbon stock $\left(C_{L}\right)$ showed significant differences (table 2) among the intercanopy, under shrub canopy and tree canopy $(\mathrm{F}=45.73 ; P<0.0001 ; \mathrm{DF}=2)$. The weighted litter carbon stock showed similar tendencies although did not differ between shrub and tree canopy treatments $(\mathrm{F}=32.35 ; P<0.0001 ; \mathrm{DF}=2)$.

When compared between districts, no significant differences were obtained for the weighted litter stocks $\left(C_{L W}\right)$, discriminating by each soil cover type (IC: $\mathrm{n}=98$; $\mathrm{F}=1.74 ; P=0.1897$. UT: $\mathrm{n}=94 ; \mathrm{F}=2.09 ; P=0.1521$. US: $\mathrm{n}=26 ; \mathrm{F}=0.82 ; P=0.3733$ ). However, the average UT:US weighted litter stock ratio differed between Northern (1.03:1) and Southern (2.45:1) Monte Districts. The average litter stock ratio for all sites was 1.52:1.

Deciduousness had a clear and significant effect over the stocks of litter accumulated above the soil (table 2), with deciduous cover almost doubling the effect of semideciduous cover, for both unweighted and weighted values $\left(C_{L}\right.$ : $\mathrm{F}=49.69, P<0.0001, \mathrm{DF}=2 ; C_{L W}: \mathrm{F}=35.87, P<0.0001$, $\mathrm{DF}=2$ ). Litter carbon stock did not significantly differ between physiognomic-functional groups $(\mathrm{F}=0.94$; $P=0.4344 ; \mathrm{DF}=3)$. Nevertheless, a tendency for higher litter carbon stock was noted for the communities of P. flexuosa (table 3). Prosopis had twice as large litterfall input as that of Bulnesia cover ( 3.03 vs. $1.50 \mathrm{Mg} \mathrm{ha}^{-1}$ when values were weighted by plant cover). Litter carbon input seems to explain soil organic carbon at both depths by significant regressions. The following regression was found for topsoil organic carbon stock: $C_{s 0-5}=6.08+0.95 * C_{L}\left(\mathrm{R}^{2}=0.30\right.$; $P<0.0001 ; \mathrm{n}=166)$. For subsoil organic carbon stock, the following regression was found: $C_{s-20}=14.87+1.33 * C_{L}$ $\left(\mathrm{R}^{2}=0.15 ; P=0.0001 ; \mathrm{n}=156\right)$ (figure 4$)$.
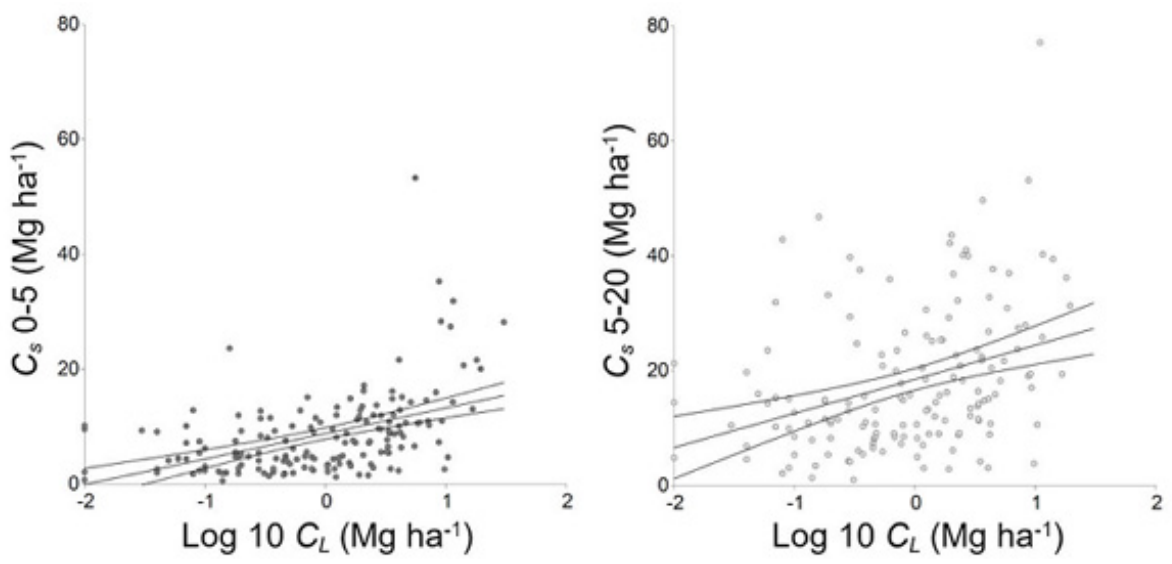

Figure 4. Soil organic carbon stocks $\left(C_{s}\right)$ at $0-5$ and 5-20 $\mathrm{cm}$ depth and Log 10 litter carbon stock $\left(C_{L}\right)$ regression. Midline: mean regression line; lateral lines: confidence bands.

Regresión entre los contenidos de carbono orgánico del suelo $\left(C_{\mathrm{s}}\right)$, a profundidades de 0-5 y 5-20 cm, y Log 10 de los contenidos de carbono de mantillo $\left(C_{L}\right)$. Línea media: función de regresión; líneas laterales: bandas de confianza. 
Dead wood (1 to $5 \mathrm{~cm}$ in diameter) carbon stocks. Trees produced substantial amounts of small branches and twigs that were deposited on the soil, significantly different from the dead wood stocks accumulated in the intercanopy (table 2). Shrubs made a modest input of dead wood, although did not differ significantly from the intercanopy $\left(C_{D W<5}: \mathrm{F}=12.97, P<0.0001, \mathrm{DF}=2 ; C_{D W<5 W}: \mathrm{F}=7.34\right.$, $P=0.0008, \mathrm{DF}=2$ ).

The litter accumulated under deciduous vegetation was twice as that of semideciduous vegetation, and it was six times larger than that in the intercanopy $\left(C_{D W<5}: \mathrm{F}=15.61\right.$, $\left.P<0.0001, \mathrm{DF}=2 ; C_{D W<5}: \mathrm{F}=8.97, P=0.0002, \mathrm{DF}=2\right)$ (table 2).

Physiognomic-functional groups did not differ significantly in the diameter $<5 \mathrm{~cm}$ dead wood inputs (table 3 ). However, there was a marginal difference between mixed woodlands and communities of $B$. retama, when compared to the communities of $S$. divaricata and P. flexuosa, with p-values at $0.1(\mathrm{~F}=2.64 ; P=0.0912 ; \mathrm{DF}=3)$. The latter accumulated large amounts of dead wood under $5 \mathrm{~cm}$ in diameter.

Dead wood (diameter $>5 \mathrm{~cm}$ ) carbon stocks. Dead wood volumes were multiplied by the following densities; P. flexuosa: $0.75 \pm 0.03 \mathrm{Mg} \mathrm{m}^{-3}(\mathrm{n}=7) ;$ S. divaricata: 0.66 $\pm 0.02 \mathrm{Mg} \mathrm{m}^{-3}(\mathrm{n}=9)$; B. retama: $0.80 \pm 0.02 \mathrm{Mg} \mathrm{m}^{-3}$ $(\mathrm{n}=9)$; G. decorticans: $0.53 \pm 0.02 \mathrm{Mg} \mathrm{m}^{-3}(\mathrm{n}=8)$.

Since the dead wood compartment was quantified independently from the identified treatments within each sample plot, it was only possible to compare among physiognomic-functional groups (table 3 ). This variable showed no statistical difference among groups $(\mathrm{F}=1.45 ; P=0.2524$; $\mathrm{DF}=3$ ). The two dead wood categories had a positive and significant relationship between each other $\left(C_{D W>5}=0.29+\right.$ $\left.1.81 * C_{D W<5} ; \mathrm{R}^{2}=0.47 ; P<0.0001 ; \mathrm{n}=30\right)$.

Total dead organic carbon stocks. The sum of the three pools (soil organic carbon, litter, and dead wood) represented significant stocks for all the four physiognomicfunctional groups (table 3). Prosopis spp. woodlands accumulated more than $38 \mathrm{Mg} \mathrm{ha}^{-1}$ of dead organic carbon, followed by Suaeda spp. woodlands with almost $35 \mathrm{Mg} \mathrm{ha}^{-1}$. Mixed woodlands, representative from Southern Monte District, showed average values around $27 \mathrm{Mg} \mathrm{ha}^{-1}$, while Bulnesia spp. woodlands were the poorest with around $25 \mathrm{Mg} \mathrm{ha}^{-1}$. No statistical differences were found among groups $(\mathrm{F}=1.84 ; P=0.1683$; $\mathrm{DF}=3)$; nevertheless, $P$. flexuosa communities were marginally different $(P<0.1)$ from $B$. retama communities, when separately compared from the rest $(\mathrm{F}=4.09 ; P=0.0614 ; \mathrm{DF}=1)$.

\section{DISCUSSION}

Deciduousness, i.e., deciduous vs. semideciduous, has a more significant effect over soil organic carbon stocks than does soil cover, i.e., tress vs. shrubs. The deciduous- ness has an important influence in the topsoil $(0-5 \mathrm{~cm})$, although its effect is diluted in the subsoil $(5-20 \mathrm{~cm})$.

Few studies have surveyed soil organic carbon stocks in arid land regions by discriminating strata within the first five centimeters of soil depth. For example, Charley and West (1975) found for Utah rangelands important differences in the soil organic carbon stocks by comparing three depths within the top $20 \mathrm{~cm}$ depth. They suggest that the lack of soil mixing, litter input, and the low precipitations in arid lands, are the leading causes of carbon layering, even within the first centimeters of soil depth.

Soil organic carbon stocks per site are strongly dependent on the proportion of soil under the canopy and off the canopy. Alvarez et al. (2009) made the same conclusions for Ñacuñán woodlands in Southern Monte. Therefore, the elimination of plant cover should have a substantial effect on the total amounts of organic carbon accumulated in arid environments.

Tree and herbaceous plant suppression may promote encroaching of semideciduous species such as Larrea spp. (Villagra et al. 2009). Shrub encroachment reduces the amount of total litter deposited in the soil by almost $50 \%$ (see $C_{L}$ under tree canopy vs. under shrub canopy in table 2 ). Since litter is the primary source of soil organic carbon, a reduction in its deposition may affect the stocks of soil organic carbon. Larrea spp., a common shrubby species in Monte woodlands, may contribute to soil carbon stocks (as Eldridge et al. 2011, state for Larrea shrublands in the USA), though it may never reach the litter input levels of Prosopis spp. due to its semideciduousness and lower canopy volume.

The average ratio between the UT:US weighted litter carbon stocks found in this work (1.52:1) is similar to the annual litterfall ratio measured by Alvarez et al. (2009), who compared Prosopis spp. and Larrea spp. litterfall (1.4 to 1.8 in 1). By district, the average ratio for the Southern Monte (2.45:1) recorded here (and where these authors made their study) surpasses those obtained by Alvarez et al. (2009), while the ratio for Northern Monte (1.03:1) is quite lower. The differences between districts are mainly due to the species found in each; no communities of $B$. retama, with lower inputs of litter, were measured in Southern Monte. Differences with Alvarez et al. (2009) might depend on the sampling moment and the input of other species rather than Prosopis spp. and Larrea spp.

The difference between the unweighted and the weighted litter input between under tree canopy and shrub canopy suggests that trees and shrubs release different amounts of litter per surface unit $\left(\mathrm{m}^{2}\right)$. However, ultimately this effect will be dependent on the relative cover of each type within each sample plot. Litter contents in the intercanopy are quite low due probably to slope effect, high rainfall intensity and, consequently, to runoff effect. Intercanopy areas are away from canopy influence, where cattle can move freely producing significant erosive impact. Such effect alters microtopography, forming pedes- 
tals under trees and shrubs, and gullies in inter-patches. During the rainy season, water moves through gullies dragging litter away.

Dead wood is an important carbon pool. Nevertheless, the fraction of dead wood between 1 and $5 \mathrm{~cm}$ in diameter represents approximately one-fifth of the litter fraction, while dead wood with more than $5 \mathrm{~cm}$ in diameter represents almost half. Both dead wood fractions are quite variable, and their inputs depend on the climatic conditions such as rainfall or wind (Alvarez et al. 2009). The values obtained for dead wood in this study are slightly superior to those reported by Woodall and Liknes (2008) for drylands in the United States. Unfortunately, these authors do not detail to which species corresponds the measured dead wood, nor the sampling season.

Deciduousness is the cause that explains the large carbon stocks found in the communities of P. flexuosa, despite the lack of significant differences $(P=0.05)$ from other plant communities. Soil organic carbon and litter are the main carbon pools in these communities. These communities are usually associated with shallow water tables, increasing the total productivity, and therefore, the amount of litter input.

In the mixed woodlands, predominantly from Southern Monte, organic carbon contents in soil and dead wood are below the average. In this group, soil organic carbon percentages are similar to those reported by Rossi and Villagra (2003) for the same district. When converted into organic matter $(f=0.58)$, weighted by soil depth $(0-20 \mathrm{~cm})$ and discriminated by quadrant and soil cover, organic matter percentages are $2.28 \%$ in under canopy and $1.14 \%$ in the intercanopy. These can be compared with $2.06 \%$ of under canopy and $0.74 \%$ of the intercanopy, obtained by these authors.

The communities of $B$. retama have the lowest total carbon stocks, also due to deciduousness. Bulnesia retama is an aphyllous species that produces small amounts of litter, and this is reflected in low soil organic carbon stocks (Tapia and Martinelli 2019).

The communities of $S$. divaricata show relevant carbon stocks as soil organic carbon at $5-20 \mathrm{~cm}$ depth and dead wood. During the dry season in the mudflats, dust is removed from adjacent denuded areas and accumulated by deposition at the feet of the shrubs, burying the topsoil organic matter and incorporating it into the soil. Such a phenomenon is quite usual in arid lands and is the cause of the soil mixing and the inclusion of organic matter into the soil, increasing subsoil fertility (Moorhead and Reynolds 1991).

The total dead organic carbon stocks in these four communities can be related to the above-ground biomass contents measured by Iglesias et al. (2012) in Telteca Reserve (figure 5). The alive/dead carbon biomass ratio for the communities of $P$. flexuosa, compared with the $48 \mathrm{Mg} \mathrm{ha}^{-1}$ of carbon in "mature forests of P. flexuosa," is 1.24. In the mixed woodlands compared with the $33 \mathrm{Mg} \mathrm{ha}^{-1}$ carbon in "mixed forests," it is 1.20 . In the $S$. divaricata communi- ties compared with the $21 \mathrm{Mg} \mathrm{ha}^{-1}$ carbon in "open forests with shrubs," it is 0.61 . Finally, in B. retama communities compared with the $8 \mathrm{Mg} \mathrm{ha}^{-1}$ carbon in "open shrublands," it is 0.31 . The latter relates with a reduced total plant cover, characteristic in the $B$. retama communities (Tapia and Martinelli 2019), a reduced litter production and a reduced decay of dead wood due to its high density and hardness.

In this analysis (and for all the four groups), we missed the soil organic carbon from below $20 \mathrm{~cm}$ of depth, which according to Jobbágy and Jackson (2000), constitute considerable stocks.

Soil organic carbon and litter stocks can be compared with other ecosystems. In semiarid Chaco, with $550 \mathrm{~mm} \mathrm{y}^{-1}$ of precipitation, Abril and Bucher (2001) report 70.5, 31.0, and $15.0 \mathrm{Mg} \mathrm{ha}^{-1}$ of soil organic carbon $(0-20 \mathrm{~cm}$ depth) for highly restored, moderately restored and highly degraded woodlands, respectively. Regarding litter stocks, these authors report 2.60, 2.29 and $0 \mathrm{Mg} \mathrm{ha}^{-1}$ for the same types of woodland, respectively. The four physiognomicfunctional groups can be compared with the moderately restored woodland in terms of soil organic carbon (ranging between ca. 23 and $37 \mathrm{Mg} \mathrm{ha}^{-1}$ for 0-20 $\mathrm{cm}$ depth) and litter stocks (ranging between $c a$. 2.5 and $5 \mathrm{Mg} \mathrm{ha}^{-1}$, by adding litter and dead wood $<5 \mathrm{~cm}$ ). Compared with a subtropical rainforest in Misiones (Argentina), with 1,800 $\mathrm{mm} \mathrm{y}^{-1}$

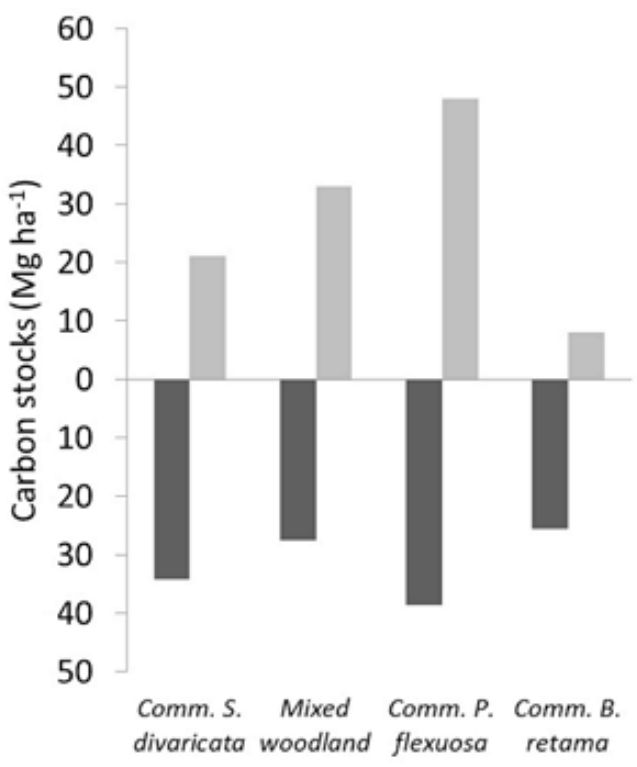

Figure 5. Carbon stocks in each physiognomic-functional group. In light gray, above-ground biomass carbon contents obtained by Iglesias et al. (2012) for Telteca Reserve; in dark gray, dead carbon biomass (soil organic carbon, litter carbon, and dead wood carbon) obtained in this study.

Contenidos de carbono en cada grupo fisonómico-funcional. En gris claro, contenidos de carbono de la biomasa aérea obtenidos por Iglesias et al. (2012) para la Reserva Telteca; en gris oscuro, el carbono de la biomasa muerta (carbono orgánico del suelo, carbono del mantillo y carbono de la madera muerta) obtenido para este estudio. 
of precipitation, the average soil organic carbon stock in Monte region is less than half. Piccolo et al. (2008) report soil organic carbon contents (at $0-15 \mathrm{~cm}$ depth) in a Kandihumult soil of $58.9 \mathrm{Mg} \mathrm{ha}^{-1}$. It can be contrasted with the $47.44 \mathrm{Mg} \mathrm{ha}^{-1}$ obtained in a closed P. flexuosa woodland (at 0-20 cm depth). The reported litter stocks in a mature rainforest, also in Misiones, are of $c a .5 \mathrm{Mg} \mathrm{ha}^{-1}$ (Vaccaro et al. 2003). Despite the evident ecological differences from rainforests, especially in soil organic carbon content, P. flexuosa woodlands have the potential for reaching slightly lesser levels of soil carbon content than that reached by rainforests.

These results partially confirm the hypothesis. The carbon contents in the intercanopy are significantly reduced compared to areas under canopy. However, trees, and especially deciduous ones, produce larger amounts of litter that affect the soil organic carbon stocks. Despite that shrubs drive the soil into reduced carbon contents compared to trees, they might be important as transitional functional types to regulate carbon stocks along successional pathways.

\section{CONCLUSIONS}

The vegetation canopy, and consequently, the litter input within fertile patches affect soil organic carbon in the topsoil. Nevertheless, carbon inputs are intimately dependent on plant functionality, such as deciduousness or canopy volume. Therefore, shrubs (especially semideciduous such as Larrea spp.) have a restricted ability to enrich the soil compared to deciduous trees such as Prosopis spp.

Soil, litter and dead wood are important pools of carbon compared to above-ground biomass in Monte region. The communities of $P$. flexuosa are the largest carbon sinks in this region. Closed Prosopis spp. formations can even be compared in terms of accumulated carbon, with ecosystems from more humid regions.

Soils and dead biomass can become significant pools of carbon storage in drylands compared to above-ground biomass. This aspect should be considered in programs on reducing emissions in arid regions.

\section{ACKNOWLEDGMENTS}

The authors would like to thank the National UNREDD Program in Argentina for the funding and the permissions to publish the present data. We would also like to acknowledge our colleagues Agr. Eng. Diego Cecaci, Agr. Tech Javier Bernasconi and Agr. Eng. Marcelo Sauer who assisted us during the field sampling, and the Agr. Engs. Carla Dionisi, Alejandro Moreno and Andrea Rubenacker for the processing of the soil and litter samples. We thank Agr. Eng. Mariana Carnero for her support in the confection of the map for the present publication.

Funding: This work was supported by the National UN-REDD Program in Argentina (Cod. CdA: LoA_ FAOAR_05_2018).

\section{REFERENCES}

Abraham E, HF Del Valle, F Roig, L Torres, JO Ares, F Coronato, R Godagnone. 2009. Overview of the geography of the Monte Desert biome (Argentina). Journal of Arid Environments 73(2): 144-153. DOI: https://doi.org/10.1016/j. jaridenv.2008.09.028

Abril A, EH Bucher. 2001. Overgrazing and soil carbon dynamics in the western Chaco of Argentina. Applied Soil Ecology 16(3): 243-249. DOI: https://doi.org/10.1016/S09291393(00)00122-0

Alvarez JA, PE Villagra, BE Rossi, EM Cesca. 2009. Spatial and temporal litterfall heterogeneity generated by woody species in the Central Monte desert. Plant Ecology 205(2): 295-303. DOI: https://doi.org/10.1007/s11258-009-9618-Z

Braun-Blanquet J. 1979. Fitosociologia. Bases para el estudio de las comunidades vegetales. Madrid, España. Blume Ediciones. $820 \mathrm{p}$.

COFEMA (Consejo Federal de Medio Ambiente, AR). 2012. Res. 230/12. http://argentinambiental.com/legislacion/nacional/resolucion-23012-bosques-nativos/

Charley JL, NE West. 1975. Plant-induced soil chemical patterns in some shrub-dominated semi-desert ecosystems of Utah. Journal of Ecology 63(3): 945-963. DOI: https:// www.jstor.org/stable/2258613

Di Rienzo JA, F Casanoves, MG Balzarini, L Gonzalez, M Tablada, CW Robledo. 2018 InfoStat versión 2018. Grupo InfoStat, FCA, Universidad Nacional de Córdoba, Argentina. URL http://www.infostat.com.ar

Eldridge DJ, MA Bowker, FT Maestre, E Roger, JF Reynolds, WG Whitford. 2011. Impacts of shrub encroachment on ecosystem structure and functioning: towards a global synthesis. Ecological Letters 14(7): 709-722. DOI: https:// doi.org/10.1111/j.1461-0248.2011.01630.x

Flores DG, G Suvires, A Dalmasso. 2015. Distribución de la vegetación nativa en ambientes geomorfológicos cuaternarios del Monte Árido Central de Argentina. Revista Mexicana de Biodiversidad 86(1): 72-79. DOI: http://dx.doi. org $/ 10.7550 / \mathrm{rmb} .40248$

Iglesias MR, A Barchuk, MP Grilli. 2012. Carbon storage, community structure and canopy cover: A comparison along a precipitation gradient. Forest Ecology and Management 265: 218-229. DOI: https://doi.org/10.1016/j.foreco.2011.10.036

Jobbágy EG, RB Jackson. 2000. The vertical distribution of soil organic carbon and its relation to climate and vegetation. Ecological Applications 10(2): 423-436. DOI: https:// doi.org/10.1890/1051-0761(2000)010[0423:TVDOSO]2.0 . $\mathrm{CO} ; 2$

Karlin UO, MS Karlin, RM Zapata, RO Coirini, AM Contreras, M Carnero. 2017. La Provincia Fitogeográfica del Monte: límites territoriales y su representación. Multequina 26: 63-75.

Martínez-Cabrera HI, CS Jones, S Espino, HJ Schenk. 2009. Wood anatomy and wood density in shrubs: responses to varying aridity along transcontinental transects. American Journal of Botany 96(8): 1388-1398. DOI: https://doi. org/10.3732/ajb.0800237

Moorhead DL, JF Reynolds. 1991. A general model of litter decomposition in the northern Chihuahuan Desert. Ecological Modelling 56: 197-219. DOI: https://doi.org/10.1016/03043800(91)90200-K 
Morello J. 2012. Ecorregión del Monte de Sierras y Bolsones. In Morello J, SD Matteucci, AF Rodriguez, ME Silva eds. Ecorregiones y complejos ecosistémicos argentinos. Buenos Aires, Argentina. FADU-GEPAMA. p. 265-291.

Navarro AF, J Cegarra, A Roig, D Garcia. 1993. Relationships between organic matter and carbon contents of organic wastes. Bioresource Technology 44(3): 203-207. DOI: https://doi.org/10.1016/0960-8524(93)90153-3

Nelson DW, LE Sommers. 1974. A rapid and accurate procedure for estimation of organic carbon in soils. Proceedings of the Indiana Academy of Science 84: 456-462.

Oyarzábal M, JR Clavijo, LJ Oakley, F Biganzoli, PM Tognetti, IM Barberis, HM Maturo, R Aragón, PI Campanello, D Prado, M Oesterheld, R León. 2018. Unidades de vegetación de la Argentina. Ecología Austral 28(1): 40-63. DOI: https://doi.org/10.25260/EA.18.28.1.0.399

Piccolo GA, AE Andriulo, B Mary. 2008. Changes in soil organic matter under different land management in Misiones province (Argentina). Scientia Agricola 65(3): 290-297. DOI: http://dx.doi.org/10.1590/S0103-90162008000300009

Roig FA, S Roig-Juñent, V Corbalán. 2009. Biogeography of the Monte Desert. Journal of Arid Environments 73: 164-172. DOI: https://doi.org/10.1016/j.jaridenv.2008.07.016

Rossi BE, PE Villagra. 2003. Effects of Prosopis flexuosa on soil properties and the spatial pattern of understorey species in arid Argentina. Journal of Vegetation Science 14(4): 543-550. DOI: https://doi.org/10.1111/j.1654-1103.2003.tb02181.x

Strada M, MG Parmuchi, E Wabo. 2011. Propuesta de Programa Nacional de Inventario de Bosques Nativos para la República Argentina. Grilla Nacional. Buenos Aires, Argentina.
Dirección de Bosques, Secretaría de Ambiente y Desarrollo Sustentable de la Nación.

Tapia R, M Martinelli. 2019. Impacto de Bulnesia retama (Zigofilácea) sobre la tasa de infiltración en un sitio piloto ubicado en la zona sur de la cuenca del Bermejo, San Juan (Argentina). Multequina 28: 47-57.

Thien SJ. 1979. A flow diagram for teaching texture by feel analysis. Journal of Agronomic Education 8(1): 54-55. DOI: https://doi.org/10.2134/jae.1979.0054

Trumper K, C Ravilious, B Dickson. 2008. Carbon in drylands: desertification, climate change and carbon finance. Istanbul, Turkey. UNEP-UNDP-UNCCD. 12 p.

Vaccaro S, MF Arturi, JF Goya, JL Frangi, G Piccolo. 2003. Almacenaje de carbono en estadios de la sucesión secundaria en la provincia de Misiones, Argentina. Interciencia 28(9): 521-527.

Villagra PE, GE Defossé, HF Del Valle, S Tabeni, M Rostagno, E Cesca, E Abraham. 2009. Land use and disturbance effects on the dynamics of natural ecosystems of the Monte Desert: implications for their management. Journal of Arid Environments 73(2): 202-211. DOI: https://doi.org/10.1016/j. jaridenv.2008.08.002

Woodall CW, GC Liknes. 2008. Climatic regions as an indicator of forest coarse and fine woody debris carbon stocks in the United States. Carbon Balance and Management 3(1): 5. DOI: https://doi.org/10.1186/1750-0680-3-5

Yang Y, A Mohammat, J Feng, R Zhou, J Fang. 2007. Storage, patterns and environmental controls of soil organic carbon in China. Biogeochemistry 84(2): 131-141. DOI: https:// doi.org/10.1007/s10533-007-9109-Z 
